\title{
MASS JUSTICE: THE LIMITED AND UNLIMITED POWER OF COURTS
}

\author{
Mark A. Peterson* \\ ANd Molly Selvin**
}

INTRODUCTION

\section{A. The Troubled Rise of Mass Tort Litigation}

That mass tort litigation has emerged in recent decades to trouble and preoccupy the American legal system should hardly be surprising. The proliferation of mass litigation, in which many plaintiffs sue a common defendant or defendants, for injuries from the same accident, or from exposure to the same product or substance, reflects the increasingly collective nature of life in the second half of the twentieth century. Mass transit accidents and disasters in large hotels and other public buildings have killed hundreds of people. The mass production and use of dozens of industrial and consumer products-some involving ambitious technologies or engineering methods-have caused similar injuries to thousands, even tens of thousands of individuals. In many instances, the mass media has been the means by which potential plaintiffs have learned of the cause of their injuries, of the opportunity to bring suit, and of developments in lawsuits that have already been filed. ${ }^{1}$ In turn, the publicity generated by new evidence on the causes of mass injuries, and by the resulting litigation, has attracted additional claimants, lawyers, experts, commentators, and even judges, raising the financial stakes of this litigation for all parties.

Mass tort litigation will continue to preoccupy our legal system. Future technological development will produce not only new, unforeseen risks to public health and safety, but will also increase our ability to identify these dangers after they have caused injuries. Moreover, the experience of lawyers and judges in handling such cases increases the feasibility of future similar

Copyright $(\mathcal{1} 1991$ by Law and Contemporary Problems

* Senior Research Scientist, Institute of Civil Justice, RAND.

* Member, Editorial Board, Los Angeles Times.

1. Mass litigation involving the drug Bendectin, which allegedly caused birth defects when taken to control nausea during pregnancy, was precipitated by a 1979 article in the tabloid "National Enquirer" describing the outcome of the first lawsuit in Florida. See New Thalidomide-Type ScandalExperts Reveal . . Common Drug Causing Deformed Babies, Natl Enquirer 20 (Oct 9, 1979), describing Mekdeciv Merkle National Laboratories, 711 F2d 1510, 1516 (11th Cir 1983) (originally filed in 1977). Newspaper accounts linking in utero exposure to the drug DES to cancer in adolescent women triggered litigation against the manufacturers of that drug. See Morton Mintz, Latent Cancer in Daughters Tied to Drug, LA Times A2 (Oct 28, 1971). 
litigation and encourages successful plaintiffs' lawyers to identify and pursue claims arising from new areas of mass tortious behavior.

But if mass litigation has become an inevitable consequence of our massoriented, technologically sophisticated world, it collides with a legal system that has evolved to process individual rather than multiple legal claims. In principle, courts process and decide each case individually; this individual consideration can involve jury trials that last days, sometimes even months. This system is not simply anachronistic or inefficient. Rather, it reflects our society's consensus as to the pre-eminence of certain important political and social values: that each litigant is entitled to a day in court and a jury of peers; that every litigant's interests and the value of his or her claim is unique; and finally, since the courts are often the last resort for those seeking redress for their grievances, that each dispute deserves careful and individual consideration.

These principles represent ideals. But the reality for most trial court litigants is quite different. The overwhelming majority of cases are settled without trial, and often without much preparation or consideration of the individual features of the case. The discrepancy between ideals and reality is even starker in mass tort litigation, where a single trial court can be the venue for hundreds, thousands, or even tens of thousands of similarly complex and vexing claims. These cases have imposed severe burdens on trial and bankruptcy courts that are underfunded and overwhelmed by mushrooming caseloads, and largely inexperienced with the enormous information problems, computer needs, and other technical issues accompanying much mass tort litigation. As a result, the processing and resolution of mass tort cases have been slow and expensive, and have produced results that sometimes seem capricious. The long delays in resolving mass tort cases have worked severe hardships on many injured plaintiffs and their families, and the differential treatment of plaintiffs with similar injuries raises concerns about inequities. Mass tort litigation can also compromise the productivity, and even viability, of defendants whether or not they are ultimately found liable, resulting in nuisance settlements of hundreds of millions of dollars. Liabilities can run into the billions. ${ }^{2}$

\section{B. The Use of Aggregative Processing}

The rise of mass tort litigation and the burdens it has imposed on courts, claimants, and parties, has led to increased use of existing legal procedures to group cases for processing and resolution. These procedures include class actions, consolidation, multidistrict litigation ("MDL"), bankruptcy, and the formation of a claims facility. Courts and parties have applied these

2. A. H. Robins' liability for Dalkon Shield claims filed in its bankruptcy proceeding was $\$ 2.4$ billion on top of hundreds of millions paid to claimants prior to bankruptcy. Asbestos defendants had paid over $\$ 1$ billion to claimants prior to the Manville bankruptcy and have paid billions more since. Those defendants may still face more than $\$ 10$ billion in claims. In re Joint Southern and Eastern District Asbestos Litigation, 129 Bankr 710 (Bankr SDNY 1991). 
procedures to mass tort cases in the belief that grouping cases will reduce litigation costs, speed disposition, and, in some instances, achieve greater equity among the parties. ${ }^{3}$

This article presents parts of our longer Institute for Civil Justice report examining the impact of aggregative procedures on mass tort litigation. Both the present article and the longer report draw on a series of case studies of seventeen mass tort litigations. ${ }^{4}$ We selected specific cases that vary across important dimensions such as: (1) the type of formal and informal aggregative procedure used, (2) the type of product, exposure or incident that generated the litigation, (3) the types of injuries that resulted, and (4) the geographical scope of the litigation and of the aggregative procedure. These differences among the cases allow us to explore a number of important questions relating to aggregation.

Our full report considers how aggregative procedures affected the collection, processing, and resolution of claims in these cases. The report emphasizes three observations. First, the use of aggregative procedures reflects and at the same time affects the interests of courts, parties, and lawyers. Second, the impact of these procedures on the course and outcome of mass litigation may have less to do with formal characteristics of procedures than on how they are applied. Third, application of procedures is shaped significantly by participants' interests. Our goals, then, have been to understand how and why participants choose and use aggregation; how aggregation affects their interests; and how aggregation serves or impedes social interests in reducing the time, expense, and inequities of mass tort litigation.

This article focuses on the role of courts in mass tort litigation. We first describe courts' interests in such cases and then consider the power that courts have to aggregate claims, describing limits on that power and the flexibility that courts have to get around limits. Finally, we examine how

3. Judges such as Jack Weinstein, Robert Parker, and Scott Wright have made important observations from their roles in various mass torts litigation. See Jack B. Weinstein, Preliminary Reflections on the Law's Reaction to Disasters, 11 Colum J Envir L 1 (1986); Scott D. Wright \& Joseph A. Colussi, The Successful Use of the Class Action Device in the Management of the Skywalks Mass Tort Litigation, 52 UMKC L Rev 141 (Winter 1984). Drawing on his experience as a special master on a number of mass tort cases, Professor Francis McGovern has offered insightful examination of this area. See Francis E. McGovern, Resolving Mature Mass Torts, 69 BU L Rev 659 (1989); Francis E. McGovern, Toward a Functional Approach for Managing Complex Litigation, 53 U Chi L Rev 440 (1986); Francis E. McGovern, Management of Multiparty Toxic Tort Litigation: Case Law and Trends Affecting Case Management, 19 Forum 1 (1983).

4. We focused our data collection on 17 instances of procedural aggregation involving mass tort litigation. These include: Agent Orange; Bendectin; Dalkon Shield; the 1981 fire at the MGM Grand Hotel in Las: Vegas; the 1981 collapse of the skywalk of the Hyatt Regency Hotel in Kansas City; the outbreak of salmonella in Chicago in 1985; exposure to chemicals used in the development of movie film in Los Angeles; exposure to DDT through contamination of rivers in Alabama; asbestos litigation in California state courts in Los Angeles, San Francisco, and Oakland (Alameda County) and in the US District Courts in Northern Ohio and Eastern Texas; the processing of asbestos claims through the Manville Personal Injury Settlement Trust, the Asbestos Claims Facility, and its successor, the Center for Claims Resolution; and litigation resulting from commercial aviation accidents (unpublished manuscript on file with authors). 
courts' interests in resolving mass tort litigation interfere with judicial promulgation and consistent application of legal rules.

II

\section{Aggregation of Cases}

The formal requirements and characteristics of the various aggregative procedures affect their availability and applicable scope, but a procedure's impact, and even the extent to which it binds parties, often depends more on the interests of parties and courts. If that interest is present, aggregation can be accomplished in a variety of ways. If parties do not see aggregation as furthering their interests, their opposition can prevent some or even all types of aggregation.

\section{A. The Strong Judicial Interest in Aggregation}

The burdens of mass tort litigation can create strong judicial interests in using aggregative procedures-interests stronger than those of plaintiffs, defendants, or lawyers for either side. Faced with mass tort litigation, judges are not simply neutral arbiters; rather, they have strong personal incentives to speed the judicial process, save costs and labor, and reduce redundancy.

Judicial concern about the costs and delay of mass litigation are eloquently expressed in a series of decisions by the Fifth Circuit Court of Appeals reviewing District Judge Robert Parker's numerous attempts to deal with the large number of asbestos personal injury claims in the Eastern District of Texas. In Jenkins $v$. Raymark Industries, Inc. ${ }^{5}$ the Fifth Circuit cited the bleak statistics about asbestos injuries: tens of millions of persons had been exposed to asbestos; annually tens of thousands become sick or die from asbestos-related diseases; and by 1983 over 20,000 asbestos lawsuits had been filed. 6 The circuit court observed that "[c]ourts, including those in our own circuit, have been ill-equipped to handle this 'avalanche of litigation' . . . Our numerous opinions in asbestos-related cases have repeatedly recognized the dilemma confronting our trial courts, and expressed concern about the mounting backlog of cases and inevitable, lengthy trial delays." 7 The court noted that approximately 5,000 asbestos-related cases were then pending in the circuit, with over 1,000 in the Eastern District of Texas alone, and that, "[d]espite innovative, streamlined pretrial procedures and large scale consolidated trials of multiple plaintiffs, the dockets of that district's courts remained alarmingly backlogged. Plaintiffs had waited years for trial, some since 1979 [seven years at the time of the 1986 opinion]-and new cases were (and still are) being filed every day."8 Five years earlier, the Fifth Circuit had

5. 782 F2d 468 (5th Cir 1986).

6. Id at 470. By 1990, well over 160,000 asbestos personal injury claims had been filed against Johns-Manville, the leading domestic manufacturer of asbestos products. By early 1991, 170,000 claims had been filed.

7. Id.

8. Id. 
suggested that the burdens on courts in handling mass litigation justified exceptional procedures. The court urged the consideration of "alternative methods for adjudicating the thousands of asbestos cases facing the courts in a manner that conserves the resources of both the courts and the parties." 9

United States district court judges Carl Rubin and Spencer Williams have each calculated the burdens that mass litigation can impose on courts. Judge Rubin estimated that his certification of a mandatory class for settling Bendectin cases saved 182 years of judicial time that would have been needed to try then-pending cases. ${ }^{10}$ In 1981 Judge Williams certified a class action for all Dalkon Shield claims in California because he determined from his "own experience in trying one nine-week case in 1980" that trial of all 165 cases then pending in that district would "bankrupt the district court's calendar and result in a tedium of repetition lasting well into the next century." 11

Judge Williams' statement reminds us that judges, as ordinary humans, have an understandable interest in escaping what many judges see as the unnecessary boredom of repetitious, individual proceedings for mass tort claims. Both trial and appellate courts cited the need to reduce or eliminate this tedious redundancy as a justification for aggregative procedures. In Jenkins, the Fifth Circuit supported Judge Parker's plan to use a voluntary class action as "clearly superior to the alternative of repeating, hundreds of times over, the litigation of the state of the art issues with, as that experienced judge says, 'days of the same witnesses, exhibits and issues from trial to trial.' "12 Even in Migues, where the Fifth Circuit overturned Judge Parker's attempt to use stare decisis ${ }^{13}$ to hold that a defendant's asbestos products were unreasonably dangerous, the Fifth Circuit expressed sympathy with the attempts by the district court to "seek ways of eliminating the need to continuously reinvent the asbestos liability wheel in every one of these cases." 14

B. Time and Cost Savings May Be Less Important to Litigants and Lawyers

Concerns about delay, the human and dollar costs, and the mind-numbing redundancy of mass litigation may be felt most strongly by courts, which face

9. Migues y Fibreboard Corp., 662 F2d 1182, 1189 (5th Cir 1981).

10. In re Richardson-Merrill, Inc. "Bendectin" Products Liability Litigation, 624 F Supp 1212, 1221-22 n6 (SD Ohio 1985); see also discussion in note 48.

11. In re Northern Dist. of California, "Dalkon Shield" IUD Products Liability Litigation, 526 F Supp 887,893 (ND Cal 1981).

12. 782 F2d at 473 .

13. Stare decisis is the legal basis for binding cases by the precedents as to matters of law in prior decisions. Judge Parker found that the prior case, Borel v Fibreboard Paper Products Corp., 493 F2d 1076 (5th Cir 1973), had decided as a matter of law that asbestos products cause lung cancer and that such products are unreasonably dangerous under Texas law. In reversing Migues, the circuit court pointed out that Borel had not decided that all future juries would have to reach these same findings and therefore was not stare decisis for Migues. 662 F2d at 1187.

14. 662 F2d at 1189 . 
a heavy press of business from other civil cases and the criminal docket, and have no incentive or strategic interest to postpone resolution of mass tort cases. In contrast, parties and their lawyers do not always share the courts' interest in minimizing the time and cost of mass litigation. In some mass tort cases both plaintiffs and defendants are interested in delaying resolution.

Defendants or their insurers may resist rapid resolution of mass tort claims when this jeopardizes their cash flow. Asbestos defendants have repeatedly opposed aggregative procedures that would require block payments to large numbers of claimants, contending that they could only pay claims over time as they generate cash. ${ }^{15}$

Rapid resolution of mass torts may be opposed even by defendants or insurers who have sufficient present funds for prompt mass payments if funds that would be used to pay claimants generate income greater than costs associated with delay. ${ }^{16}$ The sale of retroactive insurance to the MGM Grand Hotel after its disastrous 1981 fire provides a striking example. After determining that its insurance was insufficient to compensate claimants, MGM Grand sought additional funds. Insurers agreed to provide up to $\$ 200$ million dollars to claimants for a premium of under $\$ 40$ million. Insurers did not expect to pay the entire $\$ 200$ million $^{17}$ and they calculated that by the time claims were resolved and compensated, they would earn a profit on this premium. These calculations proved wrong (and insurers faced considerable losses) when MGM Grand settled claims quickly under an MDL settlement process established by Judge Bechtel. ${ }^{18}$

Defendants may have relatively little concern about the high costs of individual processing of mass tort cases where their insurance contracts place the burden of litigation expenses on the insurer ${ }^{19}$ Indeed, the structure of insurance contracts has created incentives that have led some mass tort defendants, particularly in asbestos cases, to defend claims aggressively, spending freely on litigation in order to minimize claims payment. Under present policies where litigation expenses cost insureds nothing, it is in the insured's interest to spend virtually unlimited amounts on litigation in order to postpone payments to claimants, which are assessed against the policies'

15. See minutes of the March 18, 1986 meeting of the board of directors of Raymark Industries, quoted in In re Raymark Industries, Inc., 831 F2d 550, $551 \mathrm{nl}$ (5th Cir 1987).

16. These costs include transactional litigation expenses, prejudgment interest, see Stephen J. Carroll, Jury Awards and Prejudgment Interest in Tort Cases (RAND, 1983), and higher expected future awards, see Deborah R. Hensler, et al, Asbestos in the Courts: The Challenge of Mass Toxic Torts (RAND, 1985).

17. This retroactive insurance involved multiple layers. The likelihood of payment decreased for insurers providing upper levels of coverage. If payments did not exhaust lower levels of coverage, insurers who provided upper layers would never be called upon to compensate claims.

18. In re MGM Grand Hotel Fire Litigation, 570 F Supp 913 (D Nev 1983).

19. In recent years some insurers have proposed charging defense costs against policy limits in standard commercial liability policies in response to the mounting costs of mass tort and environmental litigation. Natl Assn Ins Commrs, Proceedings 865 (1987). The National Association of Insurance Commissioners formed a committee to study this proposal and the general issues of insurance for defense costs. Although the committee concluded that some limits should be placed on defense costs, it would not accept charging defense costs against policy limits. Id at 744-45. The committee recommended further study, but the issue has not been pursued to date. 
limits. Until those limits are reached, the insurance company rather than the insureds will pay for litigation expenses. After limits are reached, the formerly insured defendants will have to pay not only the compensation dollars to claimants but also litigation costs. Thus, even if litigation expenses are greater than savings in compensation payments, delaying defendants have shifted costs of defense from themselves to their insurance companies.

Plaintiffs also may have little interest in saving time and expenses through aggregative proceedings. The high transaction costs of processing mass tort claims individually may be relatively insignificant to personal injury plaintiffs when contingent fee arrangements shelter them from most incremental costs. Some mass tort plaintiffs will be interested in postponing resolution of their claims if there is a likelihood that their medical condition will worsen over time and if they would be unable to bring a new or re-opened cause of action for their worsened condition. ${ }^{20}$

Most plaintiffs are interested in rapid resolution of their claims to compensate losses they have already suffered, but they must depend upon their lawyers to represent this interest. However, plaintiffs' lawyers often have less interest in rapid resolution of all the claims they handle than will their clients. "Boutique" plaintiffs' lawyers"1 who thoroughly prepare each case as if it will be tried cannot simultaneously prepare multiple cases for trial. They must space processing of cases in order to maximize their expected return on each. Neither can plaintiffs' lawyers who carry a large number of cases prepare all of those cases simultaneously. Both types of lawyers may find it advantageous to space the resolution of claims in order to guarantee future business and provide a steady cash flow.

Similarly, even if defendants or their insurance companies are interested in fast, low-cost resolution of mass tort cases, defense lawyers might not share those same interests. Defense law firms that are paid on an hourly basis will have little incentive to speed up and reduce the amount of work involved in resolving mass tort cases.

In short, among the parties, their lawyers, and the courts, judges almost always have the strongest interest in resolving mass litigation through the use of aggregative procedures. Grouping serves the personal interests of judges in conserving their time and labor and in minimizing uninteresting, repetitive proceedings. Aggregation also fosters the broader social goals of courts in resolving mass litigation as quickly as reasonably possible and with minimal expense.

20. Plaintiffs are placed in this position by a combination of statutes of limitation that require them to file when they know they have an injury, and state laws that do not recognize a new injury from asbestos as a new cause of action (so called "single disease" states such as Pennsylvania; see, for example, Doe v Johns-Manville, $324 \mathrm{~Pa}$ Super 469, 471 A2d 1252 (1984)). Also, even if plaintiffs do not suffer new injuries, such as lung cancer or mesothelioma, their damages will increase if their asbestosis is substantially progressive. Some courts and defendants have substituted procedures to set aside minor pleural asbestos claims ("pleural registries" or dockets) and activate those claims only if a claimant's condition worsens. However, these registries are collapsing as deterioration of defendants' financial position forces plaintiffs to accept what they can when they can.

21. Francis E. McGovern, The Cycle of Mass Tort Litigation (unpublished manuscript). 


\section{The Limited Power of Courts to Aggregate Cases}

Despite the strong social and judicial interests in expediting the resolution of mass tort cases, courts seem unable to proceed unilaterally with aggregative procedures. Rather, courts generally need the support of at least one party to the litigation.

Perhaps the classic example of such judicial dependence is the rejection of the multidistrict litigation process for asbestos by the multidistrict panel in 1977.22 The Judicial Panel on Multidistrict Litigation proposed the use of the MDL process to handle asbestos cases during the early stages of the litigation when there were far fewer claims pending. Both plaintiffs' attorneys and defendants opposed transfer of actions for coordinated MDL proceedings, pointing to the ongoing individual litigation of asbestos cases in district courts that would be interrupted by the MDL process. ${ }^{23}$ Cases that were set for trial or that had substantially completed discovery would have been delayed considerably if they were transferred into the common MDL proceedings. Faced with near universal objection, the MDL panel withdrew its motion, concluding that MDL would not necessarily serve the convenience of parties and witnesses. The panel also concluded that the unique factual issues of each asbestos case predominated over issues common to all cases, and therefore the MDL process would not promote just and efficient conduct of the litigation. ${ }^{24}$

When faced with significant opposition by plaintiffs and defendants, courts also have been unable to certify class actions in mass tort cases. Judge Scott Wright's certification of a mandatory class action for personal injury cases arising out of the Hyatt Skywalk collapse ${ }^{25}$ was opposed by both plaintiffs' lawyers and defendants who had filed claims in the state court rather than federal court. Virtually all of the serious personal injury claims had been filed in state courts before Judge Wright certified the class; certification had been sought by lawyers representing four plaintiffs who were bystanders, with less serious injury claims. Again, like the MDL panel's decision about asbestos claims, the Eighth Circuit found that the federal class action was an intrusive interruption of individual litigation that had been proceeding in the state court. Prior to the class certification half of the state suits had been settled. ${ }^{26}$ The Eighth Circuit overturned the mandatory class certification, finding that

22. In re Asbestos and Asbestos Insulation Material Products Liability Litigation, 431 F Supp 906 (Jud Pan Mult Lit 1977).

23. All but one of 55 respondents opposed MDL transfer. That single respondent, a defendant in two actions, did not argue in favor of transfer, but simply withdrew its objection. Id at 909.

24. The MDL panel considered asbestos five more times, finally ordering an MDL transfer to the Eastern District of Pennsylvania on July 29, 1991. In re Asbestos Products Liability Litigation (No. VI 1991 WL 144114 (JPML July 29, 1991). By this time the vast majority of plaintiffs favored MDL. Approximately 17,000 plaintiffs (including 14,000 plaintiffs represented by over 50 law firms) supported the transfer, while at least 5,200 opposed. Thirty defendants favored, while 454 opposed.

25. In re Federal Skywalk Cases, 93 FRD 415 (WD Mo 1982).

26. In re Federal Skywalk Cases, 680 F2d 1175 (8th Cir 1982). 
Judge Wright's order prohibiting disposition of punitive damage claims outside of the class violated the Anti-Injunction Act. ${ }^{27}$ The Eighth Circuit reasoned that actions previously filed in state court must be allowed to proceed, despite certification of a mandatory federal class. Based on this reasoning, plaintiffs' lawyers can avoid mandatory federal class actions through early filing of suits in state courts.

If there is significant opposition on the part of plaintiffs, courts seem unable to use class actions even if the defendants support use of the procedure. In 1981, Judge Spencer Williams of the Northern District of California established two class actions for Dalkon Shield cases. The first was a mandatory nationwide class action under Federal Rule of Civil Procedure 23(b)(1)(B), to hear all punitive damage claims against the A. H. Robins Company, manufacturer of the Dalkon Shield; the second was a voluntary class action under Rule 23(b)(3) to decide liability for all claims in California. ${ }^{28}$ Defendant A. H. Robins had moved for the mandatory punitive damage class, but along with virtually all plaintiffs' lawyers, opposed the voluntary California class action. The Ninth Circuit decertified both classes, finding that the voluntary Rule 23(b)(3) class was not superior to other means of adjudication, and that Judge Williams had failed to determine that Robins' funds were inadequate to satisfy claims against it, as required to form a mandatory class under Rule 23(b)(1)(B). ${ }^{29}$

More significantly, the Ninth Circuit found that refusal of all plaintiffs' lawyers to participate caused both class actions to fail the requirements of Rule 23(a). Among other requirements, Rule 23(a) states that class representatives must be typical of all class members, a requirement that could not be met by either class. The failure of "typicality" was clear for the mandatory class, because no plaintiff agreed to be the representative of the punitive damage class and none supported the class on appeal. Similarly, since no plafintiff's lawyer who was already involved in the Dalkon Shield litigation was willing to serve as class counsel, the mandatory class action could not satisfy the Rule 23(a)(4) requirement that representative parties "fairly and adequately protect the interests of the class." The district court had appointed a lawyer not previously involved in the Dalkon Shield litigation as counsel to represent the class, but the Ninth Circuit stated its "hesitan[cy] to force unwanted counsel upon plaintiffs on the assumption that appointed counsel will be adequate." 30

27. 28 USC $\$ 2283$ (1989) states that "[a] court of the United States may not grant an injunction to stay proceedings in a State court except as expressly authorized by Act of Congress, or where necessary in aid of its jurisdiction, or to protect or effectuate its judgment."

28. In re "Dalkon Shield" IUD Products, 526 F Supp 887 (ND Ca 1981).

29. In re Northern Dist of California Dalkon Shield IUD Products Liability Litigation, $693 \mathrm{~F} 2 \mathrm{~d} 847$ (9th Cir 1982).

30. Id at 851. In fact, there was no counsel representing the class at the time of the appeal. Counsel originally appointed by the court had resigned because of the substantial opposition from plaintiffs' lawyers who had been involved in the Dalkon Shield litigation, and new counsel had not yet begun to represent the class at the time of the appeal. 
Even limited opposition can subvert a mandatory class action. If significant and distinctive elements of the plaintiffs' class refuse to participate, then the representatives could not be typical of the entire class. Moreover, courts have so vigorously construed the other requirements for establishing a mandatory class under Rules 23(b)(1) and 23 (b)(2) that opposition by even a minority of plaintiffs' lawyers can prevent class certification. For example, while most plaintiffs' lawyers favored certification of a mandatory class action to effectuate a $\$ 120$ million settlement of the Bendectin litigation, a dissident minority successfully challenged the class because the district court had not made the necessary finding that the defendant's resources were insufficient to satisfy all claims represented by the class. In voluntary class actions such as the California liability class for Dalkon Shield claims, plaintiffs have a more direct means for subverting the class. As the Ninth Circuit noted: "Attorneys for the California plaintiffs who appealed assert that they will suggest that their clients opt out of the California liability class .... If they do so, the issue of a California liability class may become moot."31

Four years later, A. H. Robins again tried to form a mandatory federal class action for punitive damage claims in the face of opposition by virtually all plaintiffs' lawyers. Judge Robert Merhige refused to establish a class action, finding that the Northern District of California decision had determined that such a class did not meet requirements of Rule 23(a) and that collateral estoppel prevented Robins from again raising this issue. ${ }^{32}$

While courts cannot establish class actions in the face of significant opposition on the part of plaintiffs, they seem able to establish classes with plaintiffs' support even if defendants object. For example, Judge Robert Parker certified the Jenkins $v$. Raymark class which resolved 753 personal asbestos injury claims in east Texas, over defendants' opposition. ${ }^{33}$

Most class actions do not generate such broad support by one side and opposition by the other. More often, this procedure is favored by some but not all defendants, with significant divisions of opinions among plaintiffs' lawyers. The success of class actions under these circumstances depends, to a great extent, upon the relative interests of the parties who support and oppose the class action. These differing interests will be the subject of consideration in our forthcoming Institute for Civil Justice report.

While plaintiffs' lawyers substantially determine when class actions can be used for mass torts, defendants have the power to control the use of bankruptcies in mass tort cases. The Manville Corporation and other asbestos defendants have used bankruptcy proceedings to deal collectively with mass tort claims against them. Similarly, A. H. Robins used Chapter 11 bankruptcy proceedings to collect and develop a global resolution for all claims against the company arising out of its manufacture and sale of the Dalkon Shield. To

31. Id at 855 .

32. In re Dalkon Shield Punitive Damages Litigation, 613 F Supp 1112 (ED Va 1985).

33. Jenkins v Raymark Industries, Inc., 109 FRD 269 (ED Tex 1985). 
date, courts have not invoked the bankruptcy process for involuntary bankruptcies sought by mass tort plaintiffs but opposed by the defendant.

IV

\section{SOURCES OF JUdicial FleXibility}

Although a court's options for dealing with mass torts might be constrained by the opposition of some plaintiffs or defendants, the constraints will be only partial as long as there is support for aggregation among other parties. If parties block use of specific aggregative procedures, courts can then resort to other procedures. The cases that we studied provided several examples.

Through the MDL process, Judge Rubin retained control over most Bendectin claims even after the Sixth Circuit decertified the mandatory settlement class. The district court added to its powers under MDL through a consolidated "common issues" trial, which effectively disposed of Bendectin as a mass tort. ${ }^{34}$ The trial was mandatory only for plaintiffs filing suit in Ohio, but many non-Ohio plaintiffs participated voluntarily in order to avoid separate trials of the difficult technical issues of causation and liability. Indeed, a rush of new claims were filed in late 1985 and early 1986 to allow more plaintiffs to participate in the common issues trial, which ultimately disposed of about 60 percent of claims. Its verdict for the defense on the issue of causation effectively resolved many more. Many plaintiffs concluded that the case was unwinnable and dismissed their claims or stipulated to be bound by the defense verdict.

Similarly, Judge Parker could also have used consolidation as an alternative, if the Fifth Circuit had rejected certification of the Jenkins asbestos class action, since every member of the Jenkins class was already a plaintiff in the U.S. District Court for the Eastern District of Texas. Indeed, if he had wished, Judge Parker could have achieved an even more comprehensive resolution of asbestos cases through consolidation than he did through class certification, requiring consolidation of plaintiffs who opted out of the voluntary class. In the subsequent Cimino $v$. Raymark asbestos litigation, Judge Parker conducted mass trials as both consolidations and voluntary class actions under Federal Rule 23(b)(3) ${ }^{35}$ after the Fifth Circuit overturned a different form of class action for the same cases. ${ }^{36}$

While rejecting mandatory class actions in the Bendectin ${ }^{37}$ and Dalkon Shield litigation, ${ }^{38}$ both the Sixth and Ninth Circuits invited the district courts to certify new, presumably voluntary class actions. Neither district court chose to do so. However, after the Eighth Circuit decertified the mandatory Hyatt Skywalk class, voluntary class actions were certified in both state and

34. In re Bendectin Litigation, 624 F Supp 1212 (SD Oh 1986).

35. Cimino v Raymark, Asbestos Lit Rptr 22019 (Nov 16, 1990).

36. In re Fibreboard Corp., 893 F2d 706 (5th Cir 1990).

37. In re Bendectin Products Liability Litigation, 749 F2d 300 (6th Cir 1984).

38. In re Northern Dist of California Dalkon Shield Litigation, 693 F2d 847 (9th Cir 1982). 
federal courts. These classes accomplished the aggregative processing urged by Judge Scott Wright for this litigation. ${ }^{39}$

Judge Robert Merhige recognized the importance of aggregative processing of Dalkon Shield claims, but he concluded that he could not certify a mandatory punitive damage class sought by $\mathrm{A}$. $\mathrm{H}$. Robins because of the Ninth Circuit's prior decertification of the Northern District of California class. ${ }^{40}$ This decision intensified the litigation's strain on Robins' personnel and cash and led to the company's voluntary bankruptcy. ${ }^{41}$ Certification of the class would have given Robins respite from repeated imposition of punitive damages, at least, during pendency of the class and would have slowed all litigation while the parties struggled with the relationships between compensatory and punitive damage claims. With Judge Merhige's rejection of the punitive damages class, Robins could only gain this respite through bankruptcy proceedings. Despite his rejection of the class action, Judge Merhige obtained far greater control over the Dalkon Shield litigation and accomplished a global resolution by retaining jurisdiction in the $\mathrm{A}$. $\mathrm{H}$. Robins bankruptcy proceedings.

\section{$\mathrm{V}$ \\ Judicial Manipulation of Risk Aversion in Mass Tort Litigation}

Courts and other participants in mass tort litigation have their own, sometimes conflicting, interests in aggregating mass tort claims. Parties may see the promised economies of aggregative procedures as more important to one side than to the other or more important to the court than to either side. Parties may pursue or oppose aggregation because of strategic interests. Not surprisingly, then, procedures are not outcome-neutral in their effect on the litigation. The use of a particular aggregative procedure might substantially disadvantage one party to the litigation, while advancing the interests of others.

Aggregative procedures may also advance or impede other objectives of our civil justice system, such as the articulation, clarification, and consistent application of legal rules, and the enhancement of public safety through deterrence. Several examples from our case studies illustrate both the general potential for judicial manipulation of the uncertainties unique to mass tort litigation, and, more specifically, the possibility that courts' interests in resolving these claims can sometimes compromise the articulation and consistent application of legal rules.

39. Wright \& Colussi, 52 UMKC L Rev 141 (cited in note 3).

40. See note 38 and accompanying text.

41. In June 1985 , the company's unrestricted funds were only $\$ 5$ million, and it was unable to obtain commercial financing. In re A. H. Robins Co. Inc., 89 Bankr 555 (ED Va 1988). 


\section{A. The Unique Uncertainties of Mass Tort Litigation}

Uncertainty seems to play a substantially different role in mass tort than in ordinary tort litigation. In ordinary litigation, uncertainty may impede settlement by allowing plaintiffs and defendants to form substantially different estimates of the values of claims. Courts encourage settlements in ordinary cases by reducing the bases for parties to disagree about claim values through discovery and rulings on motions.

Both courts and parties approach mass litigation quite differently. Mass litigation involves enormous stakes-substantial recoveries for thousands of plaintiffs, wealth for lawyers, and "bet-your-company" exposures for defendants. Both sides face staggering risks when mass litigation is collected for a global resolution. In one trial, or even on the basis of one motion, parties can win or lose an entire case potentially involving billions of dollars. ${ }^{42}$

Faced with these enormous stakes, defendants' and plaintiffs' lawyers are more risk averse than in ordinary litigation where wins and losses tend to cancel out. ${ }^{43}$ Parties' risk aversion is further exacerbated by the distinctive uncertainties of mass litigation. The potential value of large numbers of claims and, consequently, the ensuing risk, can vary widely where parties are uncertain not only about factual matters but also about legal rules that will be applied to those claims.

Clever trial court judges can increase parties' willingness to settle mass tort litigation by emphasizing the enormous risks each side faces. For example, Judge Parker promoted settlement of the Jenkins asbestos class action through a common trial of state-of-the-art defense and punitive damages, the two issues that raised the greatest risk for plaintiffs and defendants respectively. ${ }^{44}$ Similarly, Judge Weinstein made settlement of the Agent Orange class more likely by shifting the first trial issue from the government contractor defense to the issue of medical causation, an issue with substantial risks to both plaintiffs and defendants and one that also made the plaintiffs' injuries more salient to the parties. ${ }^{45}$

\section{B. Ducking the Law in Mass Torts}

Mass tort cases frequently raise difficult, controversial legal issues. The ease of litigation and the value of claims may depend upon judicial decisions

42. See, for example, In re Richardson-Merrill, Inc. "Bendectin" Products, 624 F Supp 1212 (common issues trial); Peter H. Schuck, Agent Orange on Trial: Mass Toxic Disasters in the Courts 226- 44 (Belknap Press, 1986) (approval of defendants' summary judgment for opt-outs in Agent Orange); Juzwin $v$ Amtrog Trading Co., $705 \mathrm{~F}$ Supp 1053 (D NJ 1989) (limitation of punitive damages in asbestos cases).

43. In ordinary litigation defendants can afford to lose one or a few cases if, in the long run, they can expect to win others. Plaintiffs' lawyers might also take a similar attitude when they have a relatively large portfolio of claims. Individual plaintiffs, however, may not be so risk-neutral, since they will win or lose only one claim.

44. 109 FRD 269 (ED Tex 1985). See also Mark A. Peterson \& Molly Selvin, Resolution of Mass Torts: Toward a Framework for Evaluation of Aggregative Procedures (RAND, N-2805-105, 1988).

45. In re Agent Orange Product Liability Litigation, 597 F Supp 740 (EDNY 1984). See also Schuck, Agenl Orange on Trial at 114 (cited in note 42); Peterson \& Selvin, Resolution of Mass Torts (cited in note 44). 
regarding choice of law, statutes of limitations, applicable defenses (such as the state-of-the-art or the government contractor defense ${ }^{46}$ ), the availability of punitive damages, or the applicability of class actions and other aggregative procedures. Because of the novelty of most mass tort litigation, such cases often raise issues of first impression, the resolution of which may have important precedential effects.

Yet because of judicial interest in controlling, limiting, and disposing of mass litigation, courts faced with these lawsuits often fail to resolve such potentially dispositive legal issues. Indeed, some trial courts have successfully attempted to promote settlement of mass tort claims by witholding decisions on these crucial questions in order to maintain a high level of uncertaintyand, consequently, risk-for both sides of the litigation.

During the bankruptcy proceedings of the A. H. Robins Company, for example, the court did not issue a decision about the statutes of limitations to be applied to Dalkon Shield claims, a matter that would have significantly affected the evaluations of claims brought under the bankruptcy. Parties' estimates of the value of Dalkon Shield claims were less certain because they had no guidance about the applicable statute of limitations. Had the court determined the applicable statute of limitations, the parties benefiting from the decision would have been less amenable to compromise. ${ }^{47}$

The Agent Orange litigation offers repeated examples of the court's strategic manipulation of uncertainty. Throughout the litigation, Judge Weinstein avoided issuing final decisions on potentially dispositive issues. Instead, he issued statements of preliminary decisions or indications of how he might rule on those issues. ${ }^{48}$ This practice enabled the parties to get some indication of what to expect in the litigation, but maintained uncertainties about the final treatment of these issues. Judge Weinstein finally ruled on critical issues such as medical compensation, state-of-the-art, and statutes of limitations only after the litigation had been settled. Weinstein's opinion on the fairness of the settlement turned on his conclusion that plaintiffs' cases were so weak as to have little value. ${ }^{49}$ Indeed, in granting summary judgment against plaintiffs who had opted out of the class action settlement, Weinstein

46. The state-of-the-art defense holds that a defendant cannot be held liable for a defect in a product that could not have been known given the state of expert knowledge at the time the product was manufactured. The government contractor defense provides that no liability attaches for manufacturing a defectively designed product if the government designed the product by stating specifications for the product, the manufacturer met those specifications, and the government knew as much about the dangers of the product as the manufacturer knew or should have known. In re Agent Orange Liability Litigation, 597 F Supp 740, 846-47 (1984). Government immunity protects the government from liability for the defective design, and the government contractor defense extends this immunity to manufacturers who are simply supplying the government.

47. The A. H. Robins bankruptcy proceeding also illustrates that too much uncertainty can impede settlement. Parties' estimates of the value of Dalkon Shield claims varied greatly-from less than $\$ 1$ billion by A. H. Robins and equity shareholders to over $\$ 7$ billion by the plaintiffs' committee. Several companies offered to acquire allowing an agreement to pay claims and resolve the bankruptcy, but only after the court determined that the outstanding claims were worth $\$ 2.4$ billion. In re A. H. Robins Co., Inc., 880 F2d 694 (4th Cir 1989).

48. See Schuck, Agent Orange on Trial at 125 (cited in note 41 ).

49. In re Agent Orange Product Liability Litigation, 597 F Supp 740. 
determined that plaintiffs' claims had no value. If these opinions had been issued prior to the settlement, the defendants would have had no incentive for settling the litigation. ${ }^{50}$

In the context of mass litigation, issues such as choice of law, statutes of limitation, defenses, punitive damages, or causation can be exceptionally difficult. ${ }^{51}$ Courts' attempts to decide these complicated issues entail hard intellectual labor, certain criticism, and the risk of reversal, all of which can be avoided if litigation is resolved by settlement before the court is forced to decide. Postponing resolution of these complicated questions pressures parties toward settlements, which may relieve judges from ever having to decide the issues. In short, trial courts faced with mass tort lawsuits often find it in their interests to fail to articulate and address legal issues.

Appellate courts also avoid deciding difficult legal questions in order not to overturn resolutions of mass tort litigation reached by trial courts.

50. Prior to the judge's ruling, a defendant does not know with complete certainty whether its motion for summary judgment will be granted. Where, as in Agent Orange, continuing litigation expenses are great and damages are potentially enormous, a defendant might be willing to pay a substantial settlement to avoid even a low probability that a claim will survive defense summary judgment. If the claim survives summary judgment, the defendant will have to continue to meet these substantial litigation costs. Furthermore, having lost on summary judgment a defendant would face a significant possibility of a jury verdict (since in emotion-laden cases like Agent Orange, juries are more likely than judges to be moved by sympathetic plaintiffs). Where $p_{1}$ is the probability that the claim will survive summary judgment, $c$ represents the future litigation costs facing the defendant if the case goes to trial, $p_{2}$ is the likelihood of a jury verdict finding liability, and $d$ is the amount of damages, the settlement value of the claim to the defendant is

$$
p_{1} *\left[c+\left(p_{2} * d\right)\right]
$$

Assume arbitrary numbers for purposes of illustration:

$$
.1 \times[\$ 20,000,000+(.7 \times \$ 2,000,000,000)]=\$ 142,000,000 .
$$

Of course this failure to rule may not be in the interests of particular parties. For example, Agent Orange defendants would have avoided paying a $\$ 140$ million settlement if Judge Weinstein had granted summary judgment earlier. Defendants regarded this settlement almost as a "nuisance payment" equal to the amount they anticipated spending for legal expenses even if they won all litigation. An offer of $\$ 180$ million by Merrill-Dow to settle globally the Bendectin litigation is similarly commonly regarded as a "nuisance payment." Plaintiffs" lawyers involved in these cases vigorously argue that their lawsuits were not simply nuisances and should not have been subjected to summary dismissal. Plaintiffs' lawyer Barry Nace opposed the proposed Bendectin settlement and continued to pursue claims after the common issues trial. Similarly, plaintiffs' lawyer Tom Henderson opposed the Agent Orange settlement, arguing that the claims had far greater value. As we note in the last section of this article, courts' failures to address legal issues affect public interests in multiple, sometimes troubling ways.

51. For example, consideration of statutes of limitations can involve crushingly difficult issues of choice of law, for claims may have been filed in every state and many foreign nations. Jurisdictions differ markedly with regard to, for example, length of the statute period and what events trigger the statute. In the Robins bankruptcy proceedings, the applicable state laws were conjectural: most of the Dalkon Shield injury claims had not yet been filed as law suits and could have been filed in any of several jurisdictions. Furthermore, statutes of limitations in some jurisdictions, but perhaps not all, might be tolled if defendants fraudulently withheld information about dangers of the products, as claimed in both the Dalkon Shield and the Agent Orange litigation. See Morton Mintz, At Any Cost: Corporate Greed, Women, and the Dalkon Shield 149-72 (Pantheon, 1985) (claims of fraud in Dalkon Shield litigation); Schuck, Agent Orange on Trial at 190 (cited in note 42) (claims of fraud in Agent Orange litigation). 
Appellate courts have acknowledged both implicitly and explicitly the extraordinary burdens and difficulties placed upon trial courts in resolving mass tort cases. ${ }^{52}$ In turning down a number of challenges to the handling of the common issues trial in the Bendectin litigation, the Sixth Circuit Court of Appeals referred sympathetically to Judge Rubin's observation that full trials of all of the Bendectin cases would have required 182 years of judges' time. ${ }^{53}$

The Sixth Circuit's concern about protecting the judicial resources saved by the Bendectin common issues trial was evident in its treatment of plaintiffs' appeal over the exclusion of minor plaintiffs from the trial. Judge Rubin had excluded from the trial courtroom all plaintiffs who were under ten years old or had visible deformities upon representations by the defendant that the children's presence would have had a prejudicial effect on the jury. The judge neither observed the children nor held a hearing on the defendant's motion, contrary to the Sixth Circuit opinion in Helminski v. Ayerst Laboratories 54 decided after the Bendectin common issues trial but before its appeal. The Helminski court found that due process required a hearing before plaintiffs could be excluded from a civil trial. ${ }^{55}$

In reviewing the Bendectin common issues trial, the Sixth Circuit was faced with a presumption that the Helminski rule involving an issue of due process should be applied retroactively. ${ }^{56}$ Of course, retroactive application would have overturned the trial verdict that disposed of most of the Bendectin litigation. Rather than reopening the Bendectin litigation, the Sixth Circuit decided that the Helminski rule would be applied nonretroactively.

To apply the Helminski rule nonretroactively, the circuit court had to make two findings. ${ }^{57}$ First, the court had to find that the rule in question established a new principle of law either by overruling prior law or "by deciding an issue of first impression whose resolution was not clearly

52. See Hardy v Johns-Manville Sales Corp., 681 F2d 334, 346 (5th Cir 1982); Migues, 662 F2d at 1189; In re Northern Dist of California Dalkon Shield IUD Products Liability Litigation, 693 F2d at 849-50; In re Bendectin Products Liability Litigation, 749 F2d at 307; In re "Agent Orange" Products Liability Litigation, 818 F2d 145, 150-52 (2nd Cir 1987); In re Federal Skywalk Cases, 680 F2d at 1184; In re A. H. Robins Co., Inc., $880 \mathrm{~F} 2 \mathrm{~d}$ at 697 .

53. In re Bendectin Litigation, 857 F2d 290, 316 (6th Cir 1988). Although Judge Rubin's calculation in principle might have been correct, it is likely that most Bendectin cases would not have been tried even if the common issues trial had not disposed of a thousand claims. In ordinary litigation, well over $90 \%$ of trials settle. Of the more than nine thousand Dalkon Shield claims resolved prior to the A. H. Robins bankruptcy, fewer than $1 \%$ were tried. Nevertheless, even if the common issues trial of Bendectin cases saved only 18 rather than 182 judicial years, the trial courts' actions would not be overturned lightly.

54. 766 F2d 208 (6th Cir 1985).

55. Helminski held (1) that it was a violation of due process to exclude a plaintiff from a trial without first having a hearing to determine that the plaintiff's presence would prejudice the jury; (2) that the defendant bears the burden of establishing that a plaintiff's mere presence would prejudice the jury; and (3) that even if the plaintiff's presence would prejudice the jury, the plaintiff cannot be excluded if he/she can comprehend and assist counsel. Id at 216-19.

56. Cochran v Birkel, 651 F2d 1219,1223 n8 (6th Cir 1981).

57. Chevron Oil Co. v Huson, 404 US 97, 106-07 (1971). A third test specified by Huson-whether retroactive application would further or retard operation of the applicable rule-had little relevance to the issue in the Bendectin litigation. 
foreshadowed." 58 Since Helminski did not overrule prior law, the Helminski rule could be applied nonretroactively only if that rule was not foreshadowed. The court did not seriously consider whether the Helminski rule had been foreshadowed, finding that it had not been because Helminski did not rely on specific prior Sixth Circuit or Supreme Court cases. However, the language of Helminski suggested that its decision was foreshadowed, since it described the "exclusion of a party who is able to comprehend the proceedings and aid his attorney" as "infring[ing] upon fundamental standards of fairness which every litigant before a federal court has a right to expect . . . ."59

The Sixth Circuit also had to find that retroactive application would be inequitable. As its only reason for non-retroactive application of Helminski, the Sixth Circuit cited the burdens of reopening the Bendectin litigation and the resulting inequity: "the fact that a twenty-two day trial had already been concluded, and a jury verdict rendered ... is certainly a factor to be considered in determining whether or not it would be equitable to apply Helminski retroactively."60 By itself, the need for a new trial, even a twentytwo day trial, does not seem a sufficient equitable concern to avoid retroactive application of a rule of due process. New trials that result from reversals always impose burdens on the parties and the courts. Of course, reversal of the common issues trial involved not simply the possibility of a new twentytwo day trial, but also of reopening a thousand individual claims resolved through the previous trial.

Although the justification for the Sixth Circuit's decision is questionable, the effect seems sensible. As the circuit court found, the failure to hold a hearing was probably harmless error. ${ }^{61}$ If Judge Rubin had held a hearing, he almost certainly would have decided to exclude the minor plaintiffs at least for the first of the trifurcated trials on causation. The children could not have assisted counsel with either the technical issues involving causation nor with factual events that transpired when they were in utero. Moreover, their presence would likely have created sympathy that might have affected the jury's consideration of the causation issues. ${ }^{62}$ But to reach its decision, the Sixth Circuit had to elevate concerns about the burdens of mass litigation, and the value of closing the litigation, into matters of equity that superseded requirements of due process. By relying on harmless error analysis, the court also avoided review and reversal of the trial judge's actions.

Both the Second and the Fourth Circuit Courts of Appeal found "harmless error" in upholding votes by personal injury claimants in the Manville

58. Id at 107

59. Helminski, 766 F2d at 218.

60. In re Bendectin Litigation, $857 \mathrm{~F} 2 \mathrm{~d}$ at 325 .

61. Id.

62. Indeed, plaintiffs' lawyers argued candidly that the children would have assisted counsel by providing "the humanistic aspect of this litigation." Id. 
bankruptcy and the A. H. Robins bankruptcy reorganization plans ${ }^{63}$ even though those votes did not seem to comply with requirements of the Bankruptcy Act. ${ }^{64}$ The act requires that a reorganization plan be approved by (1) a majority of each class of creditors as well as (2) holders of two-thirds of the amount of that class of debt. ${ }^{65}$ In effect the bankruptcy courts in both cases treated the separate requirements of section 1126(c) as equivalent, ignoring the requirement of a positive vote by holders of two-thirds of the value of personal injury claims. Both bankruptcy courts gave every personal injury claimant one vote even though there were enormous ranges in the values of personal injury claims against Manville and Robins. ${ }^{66}$

Both appellate courts decided that the failure to accord special weight to personal injury votes was harmless error, because in each case about 95 percent of personal injury claimants approved the bankruptcy plan. ${ }^{67}$ The Fourth Circuit explicitly rejected the possibility that the 5 percent of Dalkon Shield injury claimants represented more than one-third of the value of the personal injury claims against Robins, but that possibility was not farfetched. Observers of the Robins bankruptcy agreed that most of the value of the 190,000 claims against Robins were represented by 20,000 to 40,000 serious claims involving infertility, sterilizing surgery, or other serious injuries. Prior to the bankruptcy, those types of claims often settled for values exceeding $\$ 100,000$. If most of the 7,000 Dalkon Shield claimants who rejected the Robins plan claimed such serious injuries that their damages averaged $\$ 105,000$, dissenting claimants would have represented more than one-third of the value of all personal injury claims. Contrary to the Fourth Circuit's speculation, ${ }^{68}$ it is likely that damages for dissenting claimants exceeded those of claimants approving the reorganization plan. ${ }^{69}$ Dissenting claimants tended to be represented by lawyers who were particularly selective about the claims they chose to represent. ${ }^{70}$

In short, while the substantial majorities for both bankruptcy plans suggest that the plans were approved by holders of two-thirds of the value of personal

63. In the Manville bankruptcy, $95.8 \%$ of claimants voted for the plan, Kane v Johns-Manville Corp., 843 F2d 636, 647 (2d Cir 1988); 94.38\% of Dalkon Shield claimants voted for the Robins bankruptcy plan, In re A. H. Robins, Inc., $880 \mathrm{~F} 2 \mathrm{~d}$ at 698.

64. 11 USC $\S 101$ et seq (1989). In re A. H. Robins Inc, 88 Bankr 742 (ED Va 1988).

65. 11 USC $\$ 1126(\mathrm{c})$.

66. Matter of Johns-Manville Corp., 68 Bankr 618 (Bkrtcy SDNY 1986); In re A.H. Robins Co., Inc., 88 Bankr 742, 747 (ED Va 1988).

67. See note 62 .

68. In re A.H. Robins, Inc., $880 \mathrm{~F} 2 \mathrm{~d}$ at $698 \mathrm{n} 3$.

69. The results of the "Option 1" payment plan subsequently offered by the Dalkon Shield Claimants Trust also suggests that many of the women who voted for the bankruptcy plan had claims that had little value. Over 80,000 claimants-more than $40 \%$ of those eligible to vote on the bankruptcy plan-accepted maximum settlements of $\$ 725$, presumably because their claims had little value.

70. Plaintiff's lawyers who objected to the plan tended to be those who had tried Dalkon Shield claims in the past and who objected to the reorganization plan primarily because it prevented them from suing Aetna, principals of Robins, and others in order to enlarge the amount of money available to claimants. This position was based on the perception that their claims were larger than the average of approximately $\$ 30,000$ that could be paid out under the A. H. Robins Bankruptcy Plan. 
injury claims, this was uncertain. Given that the 95 percent vote did not necessarily imply satisfaction of the second requirement of a two-thirds vote based on value, the courts might have considered the requirements of section 1126(c) of the Bankruptcy Act. The courts of appeals were willing to overlook this requirement in part because they felt that evaluation of claims to provide voting weights would cause "intolerable delays."71 But weighted voting would not have been particularly onerous, at least in the Robins bankruptcy, where the court had a relatively straightforward means to weight the value of claims in compliance with section $1126(\mathrm{c})$. The court had obtained a brief questionnaire from each of the 190,000 Dalkon Shield claimants indicating the type of injuries that they alleged. By drawing on values developed in the McGovern estimation plan, ${ }^{72}$ votes for each claimant could have been weighted for the severity and value of their claimed injuries. ${ }^{73}$

It is clear that neither the Second Circuit nor the Fourth Circuit was interested in endangering the resolution of thousands of personal injury claims by each bankruptcy plan by a close consideration of voting requirements under the Bankruptcy Act. But by avoiding this analysis through findings of harmless error, the courts of appeals have substantially diluted those voting requirements.

In approving the Robins bankruptcy plan, the Fourth Circuit also failed to consider a second limiting section of the Bankruptcy Act that prevents bankruptcy courts from discharging debts of parties other than the debtor in bankruptcy. ${ }^{74}$ The bankruptcy court had used the reorganization and a related class action law suit against Aetna and other defendants to achieve a broad resolution, which effectively terminated claims against all Dalkon Shield defendants. As a part of the negotiations on the reorganization, principals and professionals representing $\mathrm{A}$. H. Robins demanded that they be relieved of any continuing liability. This immunity from liability was a major condition of the defendants in negotiating resolution of the Dalkon Shield litigation; agreement could not have been reached on a reorganization plan without it. The condition was implemented through two related actions: (1) settlement of the class action against Aetna and other defendants and (2) an injunction under the bankruptcy plan against litigation by Dalkon Shield claimants against defendants other than Aetna or doctors accused of malpractice. ${ }^{75}$

71. In re A.H. Robins, Inc., $880 \mathrm{~F} 2 \mathrm{~d}$ at 698.

72. This was the term used to describe an estimation process by Professor Francis McGovern, the court's expert. The plan involved an extensive effort to collect data for a sample of resolved and pending Dalkon Shield claims that was designed and overseen by a consensus of experts for each party and neutral experts who assisted Professor McGovern. Experts for each party then provided estimates of the Dalkon Shield claims based on their analysis of this data. In re A. H. Robins Co., Inc., 88 Bankr at 746-47; In re A. H. Robins, Inc., 880 F2d at 700; McGovern, 69 BU L Rev 659 (cited in note 3). The first author of this article was a neutral expert in this process.

73. Peterson \& Selvin, Resolution of Mass Torts at 24 (cited in note 44).

74. 11 USC $\$ 524(\mathrm{e})(1989)$.

75. Litigation against Aetna or doctors is unlikely. The settlement of the related Breland class action effectively eliminated most claims against Aetna and potential claims against doctors were almost universally barred by statutes of limitations. In re A. H. Robins Co., 880 F2d 709 (4th Cir 1989) ("Breland Settlement") 
In reviewing the bankruptcy court's injunction, the Fourth Circuit faced a line of cases holding that the bankruptcy court may not release obligations of parties who are not the debtor in bankruptcy, even if creditors approve the release under a bankruptcy plan. ${ }^{76}$

To avoid upsetting the global resolution of Dalkon Shield claim, the Fourth Circuit again sidestepped consideration of the requirements of the Bankruptcy Act. The court upheld the bankruptcy court's injunctions, but limited its approval to the facts and equities of the Robins' bankruptcy, to

this situation where the Plan was overwhelmingly approved, where the Plan ... gives a second chance for even late claimants to recover ....,[77] and where the entire reorganization hinges on the debtor being free from indirect claims such as suits $\underset{78}{\operatorname{against}}$ parties who would have indemnity or contribution claims against the debtor

The efficacy of the lower courts' actions in resolving this mass litigation remained central to the appellate court's approval of those actions.

But the Fourth Circuit explicitly refused to articulate an analysis of this section of the bankruptcy code, opting to "leave questions concerning cases in which section 524(e) does apply for another day."79 The court's decision in the Robins bankruptcy was not a guide to other cases: "Whatever the result might be as to the application of section $524(\mathrm{e})$ in other cases, we do not think that section must be literally applied in every case . . . "80

In short, these tough mass tort cases do not make good law; they do not contribute to promulgation of clear legal rules that can be applied to subsequent disputes. Despite the richness of the important substantive legal issues that arise in mass tort cases, trial courts frequently bow to their understandable concerns about disposing of those cases: they fail to address legal issues, or they reach decisions that are inconsistent with statutory or case law. Given their administrative concerns, appellate courts allow trial judges far broader power to make decisions than in ordinary tort litigation so long as the trial court can dispose of the mass litigation.

Conclusion: Mass Torts-Compromising Ideals of Justice

Courts remain the pre-eminent institution for resolving mass injury claims. But it is not simply because they are stuck with a job no one else wants. As a society, we believe that courts are best able to provide justice-that they will carefully consider the merits of each case, balance the interests of parties,

76. Underhill v Royal, 769 F2d 1426, 1432 (9th Cir 1985); Union Carbide Corp. $v$ Newboles, 686 F2d 593 (7th Cir 1982). As precedent upholding the bankruptcy court's injunction, the Fourth Circuit could only cite dicta in a recent Fifth Circuit case, Republic Supply Co. v Shoaf, 815 F2d 1046, 1050 (5th Cir 1987).

77. In re A.H. Robins, Inc., $880 \mathrm{~F} 2 \mathrm{~d}$ at $701 \mathrm{n6-7}$. The Breland settlement provides a certain $\$ 100$ million to the 108,000 "Class B" claimants, or less than $\$ 1,000$ per claim. In contrast, the Robins bankruptcy provides $\$ 2.4$ billion to 195,000 claimants, or $\$ 12,300$ per claim.

78. Id at 702

79. Id.

80. Id. 
articulate and apply rules for society, and do all of this in a disinterested, even-handed way.

The characteristics of mass litigation have often forced courts far from this ideal. The traditional legal process cannot determine the individual merits of tens or hundreds of thousands of claims against scores of defendants. Individual consideration for plaintiffs and defendants might be preserved even in mass litigation through techniques of statistical sampling, neutral expertise, and computer analyses. ${ }^{81}$ But courts have rarely used these techniques optimally.

Courts have no special expertise in balancing the interests of present and future claimants, a tradeoff that is present in every mass tort involving latent injuries. In some cases, balancing these interests may be impossible for anyone, 82 but courts in particular have appeared ill-equipped to protect the needs of future claimants. ${ }^{83}$ Even the special expertise of courts in allocating responsibility among multiple defendants is of questionable advantage when defendants are held responsible for injuries that will be manifested in the future and where each defendant's future is uncertain.

Finally, when faced with mass torts, courts are not simply disinterested administrators of justice. Rather, the extraordinary burdens of mass litigation make them deeply interested participants. Even though judicial concerns are both worthy and reasonable, we must still be concerned about how courts balance their own interests against the interests of others as they wield their enormous power to shape mass tort cases. And we should worry that courts' interests compromise the essential judicial duties to articulate sensible legal rules and to apply those rules in a consistent manner.

81. For a discussion of the evaluation method for Dalkon Shield Claims in the A.H. Robins Co. bankruptcy and for asbestos cases in the Jenkins class action and in the Ohio Asbestos Litigation program, see McGovern, 69 BU L Rev 659 (cited in note 3).

82. Judge Carl Rubin commissioned studies costing $\$ 300,000$ to estimate the number of future claims for injuries caused by Bendectin, but the court's experts could not even devise a method with which to pursue such an analysis.

83. Estimates of future asbestos claims expected against Manville were so uncertain that they pushed the parties to an open-ended arrangement for funding compensation of such claims. Nevertheless, claims filed to date far exceed estimates made at the time of the bankruptcy, leading to reorganization of the Manville Personal Injury Settlement Trust through a mandatory class action. In re Southern and Eastern District Asbestos Litigation, 129 Bankr 710. 
